\title{
Biodiversity in my (back)yard: towards a framework for citizen engagement in exploring biodiversity and ecosystem services in residential gardens
}

Citation for published version (APA):

Beumer, C., \& Martens, P. (2015). Biodiversity in my (back)yard: towards a framework for citizen engagement in exploring biodiversity and ecosystem services in residential gardens. Sustainability Science, 10(1), 87-100. https://doi.org/10.1007/s11625-014-0270-8

Document status and date:

Published: 01/01/2015

DOI:

10.1007/s11625-014-0270-8

Document Version:

Publisher's PDF, also known as Version of record

Document license:

Taverne

Please check the document version of this publication:

- A submitted manuscript is the version of the article upon submission and before peer-review. There can be important differences between the submitted version and the official published version of record.

People interested in the research are advised to contact the author for the final version of the publication, or visit the DOI to the publisher's website.

- The final author version and the galley proof are versions of the publication after peer review.

- The final published version features the final layout of the paper including the volume, issue and page numbers.

Link to publication

\footnotetext{
General rights rights.

- You may freely distribute the URL identifying the publication in the public portal. please follow below link for the End User Agreement:

www.umlib.nl/taverne-license

Take down policy

If you believe that this document breaches copyright please contact us at:

repository@maastrichtuniversity.nl

providing details and we will investigate your claim.
}

Copyright and moral rights for the publications made accessible in the public portal are retained by the authors and/or other copyright owners and it is a condition of accessing publications that users recognise and abide by the legal requirements associated with these

- Users may download and print one copy of any publication from the public portal for the purpose of private study or research.

- You may not further distribute the material or use it for any profit-making activity or commercial gain

If the publication is distributed under the terms of Article $25 \mathrm{fa}$ of the Dutch Copyright Act, indicated by the "Taverne" license above, 


\title{
Biodiversity in my (back)yard: towards a framework for citizen engagement in exploring biodiversity and ecosystem services in residential gardens
}

\author{
Carijn Beumer $\cdot$ Pim Martens
}

Received: 12 February 2014/Accepted: 16 September 2014/Published online: 28 September 2014

(C) Springer Japan 2014

\begin{abstract}
Cultural landscapes generate many ecological values. Much of the cultural landscape exists as private or semi-private domestic gardens. These domestic gardens are hidden treasures of information on small-scale urban landscape design, urban biodiversity and the relation between citizens and their direct living environments. In this paper, an indicator framework is proposed that aims to engage citizens in experiencing and exploring biodiversity and ecosystem services in their own domestic outdoor spaces. By integrating ecological and cultural factors related to garden biodiversity the framework intends to fill a gap in existing research on domestic gardens that has until now either focused on ecological factors, or on preferences of garden owners. The framework has been developed by analysing pictures of front-yards in Phoenix (AZ, USA) and Maastricht (the Netherlands). With the BIMBY [Biodiversity in My (Back) Yard] framework we aim to contribute to an inclusive trans-disciplinary and transformational dialogue on ecosystem services, green infrastructure and biodiversity conservation in the context of the sustainable development of cities.
\end{abstract}

Keywords Biodiversity conservation - Green infrastructures · Domestic gardening · Urban sustainability $\cdot$ Ecosystem services and disservices $\cdot$ Urban design

Handled by Osamu Saito, UNU-Institute for the Advanced Study of Sustainability (IAS), Japan.

C. Beumer $(\bowtie) \cdot$ P. Martens

International Centre for Integrated Assessment and Sustainable

Development (ICIS), Maastricht University, P.O. 616,

6200 MD Maastricht, The Netherlands

e-mail: carijn.beumer@maastrichtuniversity.nl

\section{Introduction}

In this paper, we propose a framework for fostering a dialogue about the potential role of domestic gardens for the enhancement of green infrastructure and the conservation of biodiversity and ecosystem services in and beyond urban areas. According to many authors "experiencing urban biodiversity will be the key to halt the loss of global biodiversity, because people are most likely to take action for biodiversity if they have direct contact with nature (Müller et al. 2010, p. 26).” Much space in urban landscapes exists as private or semi-private outdoor spaces such as gardens, patios, courtyards, balconies and roofterraces. This means that many citizens may have their main experiences with urban biodiversity in their own gardens (Dunn et al. 2006; Cilliers 2010; Millard 2010). It also means there is a great and still largely unexplored potential to increase biodiversity, green infrastructures (Rudd et al. 2002; Tzoulas et al. 2007; Cameron et al. 2012) and related ecosystem services (Costanza et al. 1997; TEEB 2009, 2011; Costanza et al. 2014) in the context of urban sustainable development. Finally, domestic gardens are hidden treasures of information about small-scale urban landscape design, urban biodiversity and the relation between citizens and their (direct) living environments (Miller and Hobbs 2002; Galluzzi et al. 2010; Goddard et al. 2010; Cameron et al. 2012; Van Heezik et al. 2012; Kurz and Baudains 2012).

Cities and citizens are becoming increasingly recognised as important players for the implementation of international environmental agreements like the Convention on Biological Diversity (CBD) (Müller et al. 2010; Puppin de Oliveira et al. 2011). As more than half of the world population lives in cities (Butler and Spencer 2010), it will be important to embed 
conservation efforts in urban environments and human lifestyle-practices (Cilliers 2010). Citizens can become important agents in creating ecological connectivity within and beyond cities (Rudd et al. 2002) and by contributing to biodiversity conservation through greening their own yards (Miller and Hobbs 2002; Rudd et al. 2002; Galluzzi et al. 2010; Goddard et al. 2010; NWF 2013). The need for inclusion of cities and citizens in conservation practices is also reflected in strategic goal A of the Aichi Biodiversity Targets: it aims to "[a]ddress the underlying causes of biodiversity loss by mainstreaming biodiversity across government and society (CBD 2011)."

A still underexplored way of engaging citizens for conservation and sustainability is through involving their domestic outside spaces in the debate. We address this gap by proposing a framework that addresses ecological and cultural elements that can be encountered in domestic gardens. Yard-management decisions impact socio-ecological systems in various ways, for example, through irrigation patterns, fertilization or the use of pesticides (Larson et al. 2010), or through the choice for exotic species that may become invasive over time (Kendal et al. 2012). But yard-management decisions can also positively influence the presence of pollinators (Gaston et al. 2005a; Smith et al. 2006; Matteson et al. 2008; Goddard et al. 2010; Samnegård et al. 2011) improve soil quality (Dewaelheyns et al. 2013) or even foster small-scale 'Wildlife Habitats' (NWF 2013) or 'Garden Reserves' (IVN 2013) that can function as stepping stones for biodiversity and increase connectivity of the wider environment (Rudd et al. 2002; Cameron et al. 2012).

Most research on the household-parcel scale until now has been focusing on either ecological garden-structures and -features (e.g. Cornelis and Hermy 2004; Gaston et al. 2005b; Hope et al. 2006; Baker and Harris 2007; Burghardt et al. 2008; Loram et al. 2008; Martin 2008; Kendal et al. 2012), or on factors that influence human choices and preferences for certain types of yards (Nassauer 1995; Larsen and Harlan 2006; Larsen and Swanbrow 2006; Lyytimäki et al. 2008; Larson et al. 2009; St.Hilaire et al. 2010; Zheng et al. 2011; Van Heezik et al. 2012; Kurz and Baudains 2012). Although urban residential landscapes and domestic gardening preferences, values and drivers are increasingly studied in the context of sustainable development and biodiversity conservation (Miller and Hobbs 2002; Gaston et al. 2005b; Larsen and Harlan 2006; Mathieu et al. 2007; Loram et al. 2008; Galluzzi et al. 2010; Goddard et al. 2010; Larson et al. 2010; St.Hilaire et al. 2010; Chowdhury et al. 2011; Zheng et al. 2011; Cook et al. 2012; Van Heezik et al. 2012; Kurz and Baudains 2012), there is still much to be learned on how cultural elements and human preferences represented in domestic gardens (e.g. design style, maintenance need, artefacts) influence habitat value, ecosystem services and sustainability in and beyond human settlement areas (Dunn et al. 2006; Galluzzi et al. 2010; Larson et al. 2010; Chowdhury et al. 2011; Cook et al. 2012; Van Heezik et al. 2012).

Integrative approaches that combine ecological and cultural factors in domestic landscaping practices and design are available but scarce (Larson et al. 2010; Cook et al. 2012). In order to facilitate pioneers in this area, we developed an instrument to increase awareness and to stimulate dialogue and knowledge co-production on the values, uses, and small-scale biotic and abiotic structures that enhance or hinder the quality, richness and abundance of biodiversity in and beyond urban areas.

Based on an analysis of pictures taken of front-yards in Maastricht (Netherlands) and in Phoenix (AZ, USA), we developed a framework that can be considered to assess domestic garden biodiversity, ecosystem services (Costanza et al. 1997; Groot et al. 2002b; Norton and Noonan 2007), disservices (Lyytimäki et al. 2008) and the way gardens are used, maintained and valued by their owners in a trans-disciplinary and participatory way. We call the framework BIMBY, which is an acronym for Biodiversity in My (Back) Yard.

\section{Materials and methods}

The starting point for developing this framework has been the 'pigeon paradox', the assumption made by Robert Dunn and his colleagues (Dunn et al. 2006) that global conservation can be advanced when citizens are promoted to have more direct positive experiences with urban species (e.g. through feeding pigeons or other birds) (Dunn et al. 2006). Furthermore, the key concept of ecosystem services (Costanza et al. 1997, 2014; MEA 2005; TEEB 2009, 2011) has helped to structure the BIMBY framework and its indicators towards a tool that enables looking beyond biodiversity and towards its meaning in the context of (urban) sustainability. The framework development went through an iterative process: based on recurrent evaluations of literature and empirical data and their role and contribution to the emerging framework. Three main phases resulted into different 'products' that were used to construct the framework (see Box 1). The final result presented in this paper is the BIMBY framework itself.

Phase 1: gathering information

\section{Neighbourhood visits}

In order to develop a framework that is both robust and at the same time flexible enough to use in various 


\begin{tabular}{|c|c|}
\hline Phases of framework development & Products \\
\hline $\begin{array}{l}\text { Phase 1: Gathering Information } \\
\text { a. Neighbourhood visits Phoenix and Maastricht } \\
\text { b. Literature Research }\end{array}$ & $\begin{array}{l}\text { Phase } 1 \\
\text { a. Photos and notes } \\
\text { b. Indicator selection }\end{array}$ \\
\hline $\begin{array}{l}\text { Phase 2: building the BIMBY framework } \\
\text { a. Developing preliminary indicator set } \\
\text { b. Pilot analysis of photos }(\mathrm{N}=512) \text { with preliminary indicators } \\
\text { c. Evaluation sessions of methodology and indicators }\end{array}$ & $\begin{array}{l}\text { Phase } 2 \\
\text { a. Indicator set } \\
\text { b. Pilot results } \\
\text { c. Adjustment criteria }\end{array}$ \\
\hline $\begin{array}{l}\text { Phase } 3 \\
\text { Adjusting indicators and framework }\end{array}$ & $\begin{array}{l}\text { Phase } 3 \\
\text { BIMBY framework }\end{array}$ \\
\hline
\end{tabular}

Box 1 Phases of framework development

climatological, eco-systemic and cultural settings, two substantively different cities (different size, climate, biophysical conditions, culture, history, demographic structure, urban design) have been chosen as pilot case areas: Maastricht and Phoenix (see Box 2 for a more detailed description of both cities and their context). We visited easily accessible front-yards in six neighbourhoods in Phoenix and six neighbourhoods in Maastricht. We included centrally located neighbourhoods, peripheral and semiperipheral suburbs, and neighbourhoods that are part of the larger agglomeration. We also included different neighbourhood ages (built $0-10,10-30,40-70$ and 80 or more years ago), and different housing prices based on high income, middle income, lower middle income and low income (based on information from real estate websites). However, selection was also based on accessibility and mobility criteria for the field researcher. The neighbourhood visits took one day per neighbourhood in spring and early summer of 2013. During the neighbourhood visits, the lead author of this paper took photos and field notes of her visual and other sensory observations.

\section{Literature research}

In the literature research phase the visually gathered information was interpreted in the context of existing research on residential yards and human preferences. Also we compared existing indicator sets and methods for assessing (urban) biodiversity (Hermy and Cornelis 2000; Nagendra 2002; Spellerberg and Ferdor 2003; Keylock 2005; Martin 2008; Tzoulas and James 2010; FarinhaMarques et al. 2011). Generally, the existing research and indicators did not combine ecological, cultural and preference-related factors in a way that can be called scientifically integrative and easily approachable for the general public at the same time. Therefore, the BIMBY framework draws on elements from a variety of articles: the method for a rapid assessment of urban biodiversity from Tzoulas and James (2010); the categorisation of habitat types as used in Martin (2008) and Larson et al. (2010); the ecological assumption that structural and compositional patterns in ecosystems can be used as an indicator for the biological diversity (Noss 1990; Cornelis and Hermy 2004; Hart 2007; Tzoulas and James 2010) and other insights from literature on biodiversity indicators (Noss 1990; Nagendra 2002; Spellerberg and Ferdor 2003; Keylock 2005; Caro 2010; Tzoulas and James 2010), urban and garden biodiversity (Bolund and Hunhammar 1999; Savard 2000; McKinney 2002; Zerbe et al. 2003; Gaston et al. 2005b; Baker and Harris 2007; CBD 2007; Loram et al. 2008; Sukopp 2008; Dearborn and Kark 2009; Galluzzi et al. 2010; Müller et al. 2010; Beatley 2011; Müller and Kamada 2011; Jim 2013; Jorgensen and Keenan 2012; Kendal et al. 2012); on literature on biodiversity governance at the urban scale (Miller and Hobbs 2002; Zerbe et al. 2003; Goddard et al. 2010; Francis and Lorimer 2011; Müller and Kamada 2011; Puppin de Oliveira et al. 2011) and on literature on gardening styles and preferences (Larsen and Harlan 2006; Larson et al. 2010; St.Hilaire et al. 2010; Cook et al. 2012; Kurz and Baudains 2012). Finally, we searched the literature for valuable information on ecosystem services connected to urban biodiversity and more specifically on ecosystem services that can be found in residential yards (Costanza et al. 1997; Opschoor 1998; Nunes and van den Bergh 2001; Appleton 2002; Groot et al. 2002a; McNeely et al. 2005; MEA 2005; Norton and Noonan 2007; Lyytimäki et al. 2008; TEEB 2009; Hancock 2010; Shin 2012; Qviström 2013). 
In order to develop the BIMBY framework, we carried out two case studies on residential urban green in two totally different climatological zones: the temperate climate of the city of Maastricht in the Netherlands that allows for lush, diverse and green vegetation and the extreme desert climate of Phoenix in Arizona (U.S.) which comes with many challenges in the context of urban greening and gardening (Larsen \& Harlan, 2006; Martin, 2008; St.Hilaire, et al., 2010).

Maastricht and Phoenix have comparable basically 'western oriented' cultural settings but are worlds apart at the same time. Maastricht is part of a triangle of European countries (Euregio). Phoenix has many immigrants from Latin American countries -especially Mexico -- and a number of Native American reservations in its near proximity. The number of inhabitants in both cities differs greatly as does the space and the composition of the urban environment: Maastricht is a small Provincial capital city with around 121.000 inhabitants (CBS, 2013). It has its roots in Roman and Medieval European history. Maastricht has a relatively high population density which is built around a core historic centre. Phoenix is the metropolitan capital city and largest city of the state or Arizona in the U.S. It is a new world city founded only in 1861, counting almost 1.5 million people in the city itself (USCB, 2013b) and almost 4.5 million inhabitants in the greater metropolitan area (USCB, 2013a). Phoenix has a relatively small high rise built downtown centre, where some commercial activities and the city's governmental activities take place. The Phoenix residential environment is highly dispersed. Most neighbourhoods consist of floor-level bungalows with often a spacious front and back yard.

Outside of the city and agglomeration boundaries, both Phoenix and Maastricht are surrounded by natural and/or semi-natural landscapes that give space to native wildlife and plant species. Both cities also have - relative to the city size-- some spacious nature parks, like South Mountain, Papago Park, the Echo Canyon Trailhead and Piestewa Peak Park in Phoenix; and the Savelsbosch, Pietersberg and Frontenpark in Maastricht. These 'natural areas' provide potential connectivity to the ecosystems and wildlife of the larger regions and they provide access-routes for some species right into the urban areas.

Box 2 Case study Selection

Phase 2: developing the framework

\section{Developing preliminary indicators}

In order to equip our framework with accessible and graspable indicators, we mediated between biotic and abiotic yard-features and the comprehensibility of the framework. Some trade-offs had to be made to keep the model understandable for non-scientists. We decided, for example, to exclude elements such as species names and chemical soil composition, but focused instead on abundance and variations of plants, included broad animal categories, and asking for soil cover types. Decisions were also taken based on suggestions for further research made in the assessed literature. This process finally resulted in the first indicator set that involves both ecological and cultural factors. The decision process also lead to the exclusion of indicators for ecosystem dynamics and functional relations (see Box 3) as they were found too difficult to understand by non-ecologists. 
In the BIMBY framework, we did not explicitly include dynamic and functional relationships of biodiversity as indicators (Noss, 1990; Grimm et al., 2000). From an ecological point of view that may be a violation, but including such relationships would require more detailed ecological knowledge than most potential participants to the framework possess. It would over-complicate the framework as a suitable and effective object for citizen science. Nonetheless, new insights on ecological relationships may become apparent by patterns that will emerge from a quantity of observations and gathered data. Trained ecologists can use the emerging data to analyse and map such dynamic functional relationships by comparing them to data from other ecological datasets. Connecting the BIMBY data to results of surveys, interviews or socio-economic data can help increase insights in how social factors and ecological factors co-evolve in complex urban ecosystems.

Box 3 Exclusion of Ecosystem Dynamics and Functional Relations

\section{First pilot analysis}

In our first statistical analysis (using IBM SPSS Statistics 19) of the photos $(\mathrm{N}=512 ; \mathrm{N}=185$ for Phoenix and $\mathrm{N}=328$ for Maastricht), we tested the new indicator set for the total sample. We rendered a Kolmogorov-Smirnov test, made histograms, normal Q-Q plots, detrenched normal Q-Q plots and box-plots for checking on outliers and for testing normality (Beumer and Martens, in review). The results of this first pilot analysis helped to define lower, medium and higher levels of garden-contributions to biodiversity in the samples on a scale from -10 (damage to biodiversity) to 50 (very high contribution to biodiversity) (see Table 1) (Beumer and Martens 2014). It also helped to further sharpen the indicator framework in reconsidering the inclusion of indicators based on identifying visual elements available in the gardens (e.g. plastic mulch was not encountered in the existing literature, but present in many yards), or values given to elements of the indicator set.

\section{Evaluation sessions}

To further evaluate the indicators that emerged from the first pilot-results, we organised one small group evaluation sessions and one session of individual consultations with stakeholders. We wanted to see whether both ecologists and non-ecologists would easily understand the indicator framework. Also we wanted to see whether the framework would be considered useful by different groups of stakeholders. The group evaluation session involved six colleagues of various disciplinary backgrounds (social science, ecology, economy, innovation management and philosophy). All of them have been as well trained as sustainability scientists. In the group session the inclusive approach combining ecological, cultural and preference factors was valued. However, the main conclusion of the group session was to keep the framework simple in order to become an applicable tool for participatory research.

In the individual consultation session different potential stakeholder groups were represented: citizens $(n=2)$, governance $(\mathrm{n}=3)$, design $(\mathrm{n}=2)$ and commerce $(\mathrm{n}=1)$. These representatives individually reflected on the final selection of indicators to make sure they are comprehensible to them. One citizen's feedback was that it was interesting to go into the garden with the framework as it provided a new perspective on what a garden is. However, she also found it a bit difficult to immediately understand

Table 1 Descriptive statistics diversity contribution on total sample level $(N=512)$

\begin{tabular}{lcc}
\hline & Statistic & SE \\
\hline Mean & 15.5801 & 0.39378 \\
$95 \%$ confidence interval for mean & & \\
Lower bound & 14.8065 & \\
Upper bound & 16.3537 & \\
$5 \%$ trimmed mean & 15.6050 & \\
Median & 15.0000 & \\
Variance & 79.391 & \\
SD & 8.91015 & \\
Minimum & -5.00 & \\
Maximum & 47.00 & 0.108 \\
Range & 52 & 0.215 \\
Interquartile range & 12.00 & \\
Skewness & 0.69 & \\
Kurtosis & -0.150 & \\
\hline
\end{tabular}


the meaning of all the layers of the framework. It required some studying. The governance representatives (spatial planning) were interested in how the tool would be able to link domestic gardens to broader landscapes and green infrastructures beyond cities. Including domestic gardens to the idea of green infrastructure was a novel and promising approach in their view. The two designers (landscape architecture and architecture) immediately asked whether they could collaborate in order to better integrate biodiversity concerns into their concepts.

However, the main feedback given by almost all evaluators was that in order to become an attractive participatory and transformative tool the BIMBY framework needs to be simplified and further developed towards becoming a playful visual game.

Phase 3: adjusting the indicators and the framework

In the third phase we adjusted the indicators and the framework based on many suggestions made in the evaluation sessions (see Fig. 1; Table 2). The layers of the conceptual framework, for example, were clarified by adding colours for the key sections: green for the ecological factors, red for the cultural factors and blue for the issues that are dependent on human valuation (see Fig. 1). Also we increased the meaning of the BIMBY framework in a broader landscape setting by including a qualitative indicator that enables describing the context and location of the studied yards. Another example of adjustments based on the evaluations was to reposition maintenance features like pesticides and herbicides into a separate category that was called 'signs of conflict' (see Fig. 1). Some other signs of conflict were added as well.

In a follow-up project a larger number of non-academic citizens will be asked to take part in the co-development of the framework towards an effective tool for transformative trans-disciplinary science.

\section{Methodological limitations}

The development of the BIMBY framework has been framed by some practical and temporal limitations: due to the analysis based on photos, we were only able to assess directly visible biotic and cultural indicators. Less tangible and dynamic aspects such as animal species, pesticide use, irrigation, disease or subjective impressions can only be meaningfully explored on-site and in consultation with garden owners. Further on-site empirical testing and further

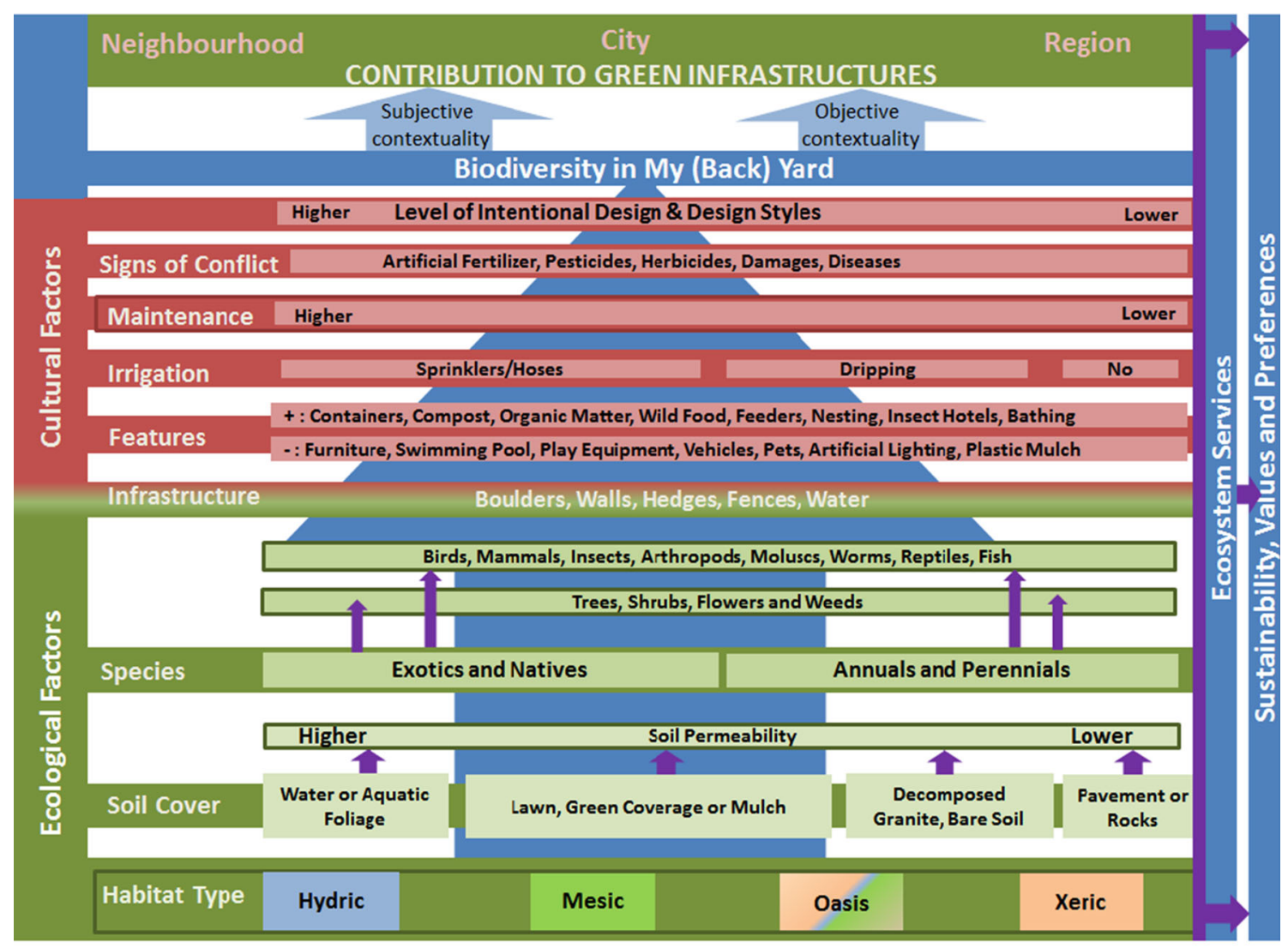

Fig. 1 Conceptual structure of BIMBY framework 


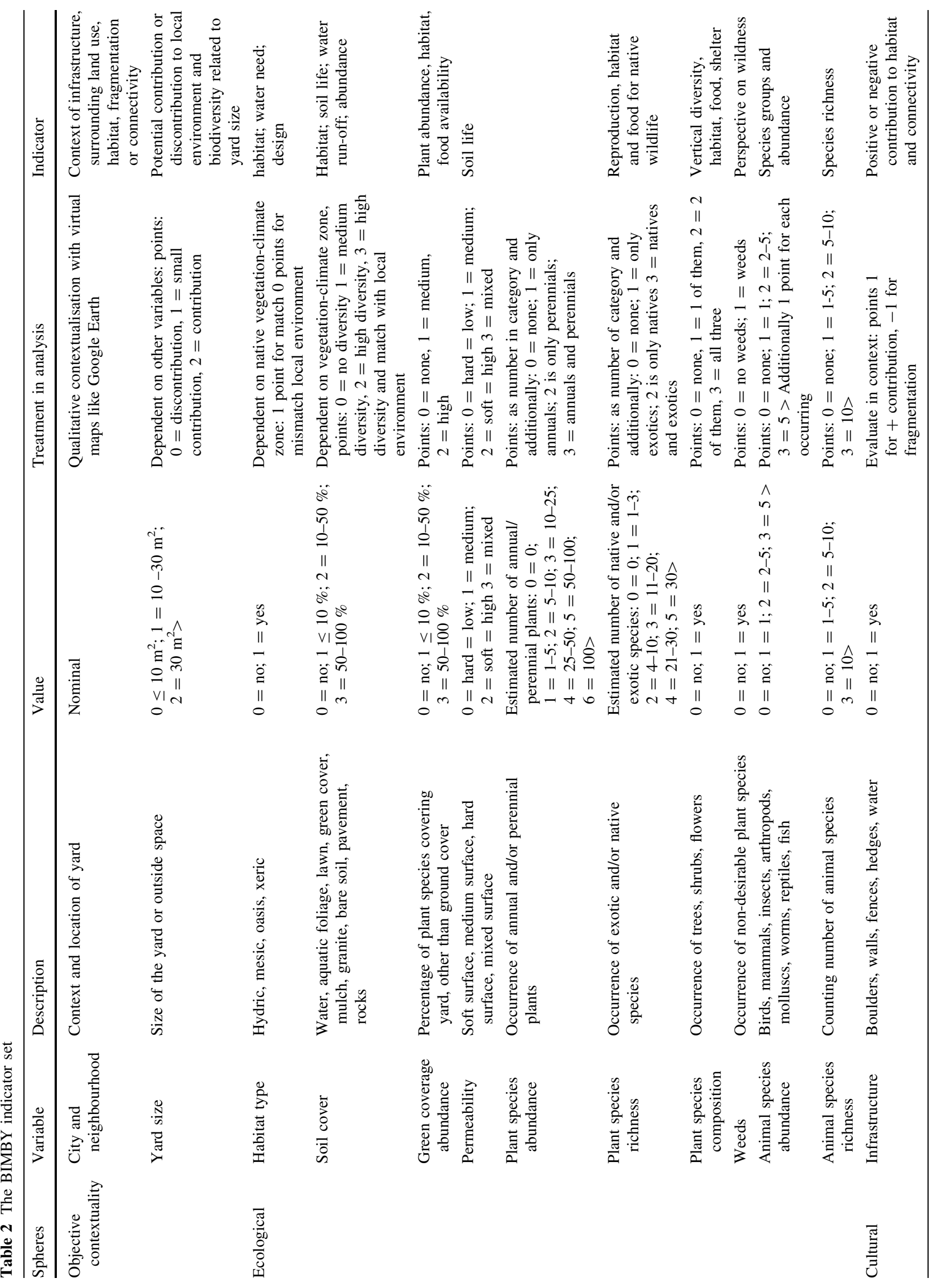




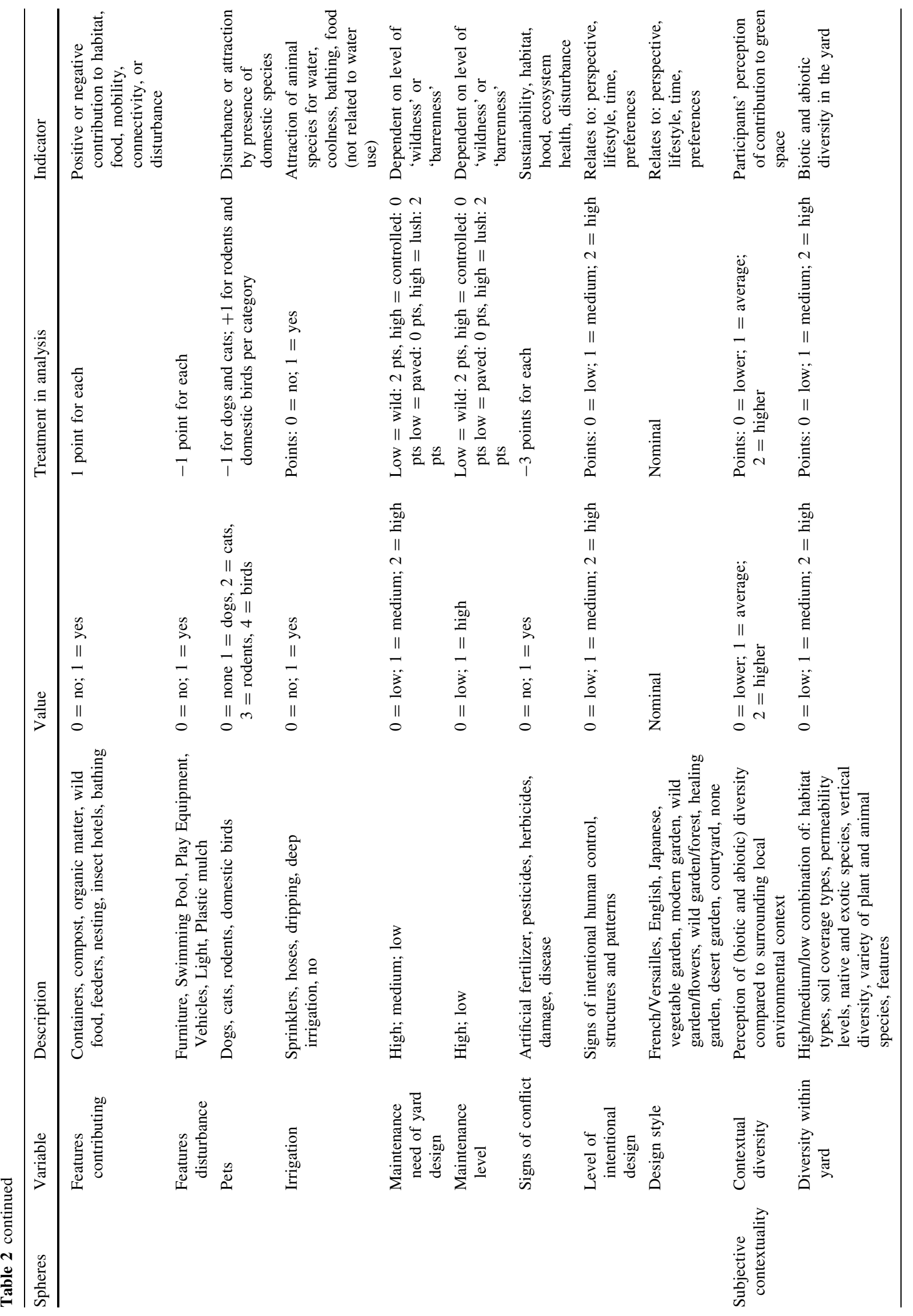




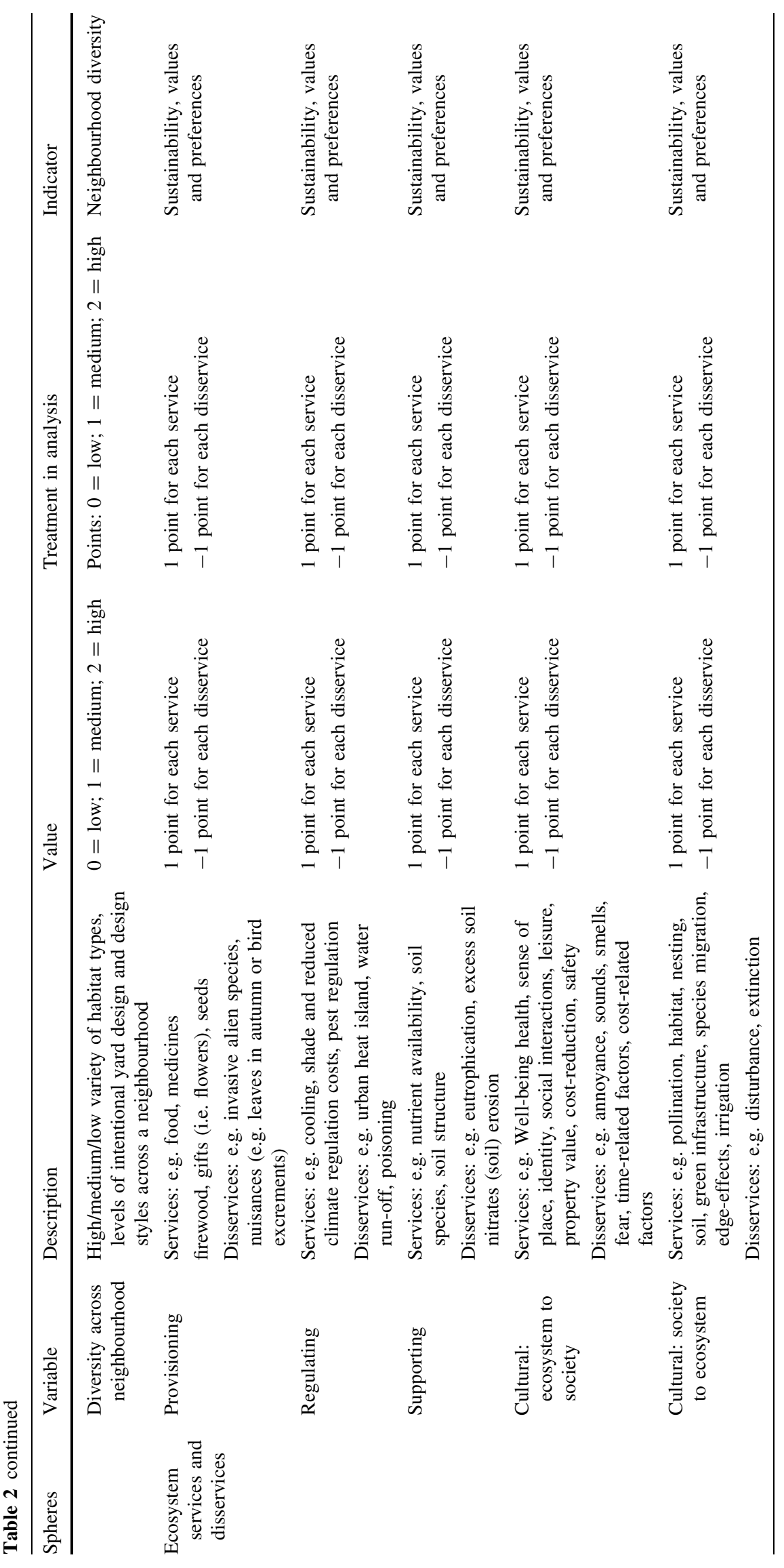


evaluating and adapting the tool towards differences in cultural and eco-systemic settings with various stakeholder groups and non-expert citizens will be a crucial task for the next phase of the development of the indicator framework if it has to become a meaningful and inviting tool for transformative knowledge production (Lang et al. 2012; Wiek et al. 2012).

\section{Results}

The main result of our project is the BIMBY framework itself. This framework consists of two parts: (1) a visual conceptual framework and (2) an indicator set. Below we describe these elements in more detail. The results of the full pilot analysis of eight neighbourhoods in Phoenix and Maastricht are presented in Beumer and Martens (2014).

The structure of the conceptual BIMBY framework

A visual representation of the BIMBY framework is pictured in Fig. 1. The framework can be read from the bottom to the top (the reading direction is represented by the thick blue arrow). It is structured around the core components of the ecological factors section and the cultural factors section, with infrastructure as a more fuzzy line in the middle.

The bottom of the framework is defined in terms of ecological indicators representing the amount of potential moisture take-up occurring in a specific habitat: the mesic (high moisture take-up), xeric (low moisture take-up) and oasis (mixed moisture take-up) habitat types (Martin 2008). For wetter contexts, we also added the hydric habitat type (e.g. lakes or wetlands) to the analysis (Davies et al. 2004).

The next bar of the framework describes the type of soil 'coverage' which also relates (see purple arrows) to the level of soil permeability and soil nutrition (Vrščaja et al. 2008; Davis and Whiting 2013). We differentiated between four types of easily identifiable soil coverage: water or aquatic foliage, lawn, green low growth foliage, decomposed granite or mulch, bare soil, and pavement. The soil cover types also relate to the level of moisture of the four habitat types, the level of soil permeability and it is an indicator for the level and quality of soil life.

The following bar in the framework is defined to indicate the variety of species. Without assuming that most people can make a basic distinction between native and exotic species, we still included this distinction in the framework. Because this indicator is very complex it should be treated with great caution. It may be better suited to find assumptions on what people believe are native or exotic species, instead of finding results that can be counted as objective facts.

Next, there is space to mention the occurrence and abundance of trees, shrubs, flowers and weeds. This bar aims to indicate the presence of an edge effect in the yards (Casey 2011). Edges are "the transition areas between adjacent habitats (Hart 2007, p. 103) and are recognised as areas of increased biodiversity (Hart 2007; Casey 2011). Nevertheless, edges can also create a loss of biodiversity, especially when they are anthropogenic alterations of (horizontal) landscapes leading to habitat fragmentation. This can lead to species isolation (Hart 2007) and even extinction (Diamond 1975; Rudd et al. 2002).

The vegetation structure and composition and the species richness and abundance are important indicators for the biological diversity of landscape patches (Tzoulas and James 2010). In the BIMBY framework it is possible to indicate the presence and abundance of animal categories: birds, insects, mammals, arthropods, molluscs, worms and reptiles. Both the plant and animal species can be more precisely described when participants know their names, but they can also just be categorised into the broader categories by counting the occurrence of individuals from the species groups. A special section is the intermediate bar between eco-systemic and cultural factors. It is characterised by infrastructural components like hedges, fence, water or walls that either increase or obstruct connectivity.

The third section of the framework consists of cultural factors. We included this section because people are the most important shapers of the urban ecosystem (Grimm et al. 2000; Müller et al. 2010). Many objects people use and the design they apply to their yards directly or indirectly provide ecosystem services (Groot et al. 2002b) or disservices (Lyytimäki et al. 2008) to animals or plant species. At the same time, garden designs and levels of maintenance and care can help providing information about the values, preferences, lifestyles, and the ecological knowledge and awareness of the garden owners. Firstly, we distinguished factors potentially contributing to biodiversity: plant-containers, compost, organic materials such as fallen branches, leaves or decomposing wood, wild food sources (i.e. berry carrying shrubs), water-features such as fountains, ponds or bird-baths, animal feeders and nesting facilities such as bird-houses or insect hotels. Secondly, we distinguished potential disturbing features which point towards a level and style of human usage of the yard and could potentially scare away small animals. We included furniture, swimming pools, play equipment, pets, vehicles, plastic mulch and pollution by artificial light (Lyytimäki et al. 2008).

On the succeeding bar, we look for the visible presence of irrigation systems, such as sprinklers, hoses and dripping systems. We include this as a positive indicator for the attraction of animal species and plant growth (Gandy 2004; 
Palmer et al. 2010; St.Hilaire et al. 2010; Mee 1990), but relative to the environment where irrigation systems are used, irrigation can also point towards unsustainable use of water. In the desert biome of Phoenix, for example, this is a pressing issue (Zube et al. 1986; Larsen and Harlan 2006; Larsen and Swanbrow 2006; Martin 2008; Larson et al. 2009; Palmer et al. 2010; St.Hilaire et al. 2010; Mee 1990; DBG 2013). This means that contextualisation of the indicators and the data is always of crucial importance to gain a better understanding of broader sustainability questions related to biodiversity.

Next, the framework intends to indicate the level of yard-maintenance (higher or lower maintenance). We also include the level of intentional design, design style and the need for maintenance of the specific design style as cultural indicators. This indicator may provide more information about the way yard-preferences are connected to lifestyles and the way people perceive and care for the world. Nevertheless, caution must always be in place when interpreting these factors without more qualitative information on (cultural) context and information given by the yard-owners themselves, for example, through surveys. Research has also pointed out that in many cases (especially in the US) front-yards represent other factors like inheritance, social- and neighbourhood norms or restrictions imposed by Home Owner Associations (HOAs) more than individual design-preferences and choices (Chowdhury et al. 2011; Cook et al. 2012).

Together, the ecological and cultural factors point towards the experience of ecosystem services and disservices and their relation to values, preferences and sustainability (right side of Fig. 1). The total picture integrates objective and subjective criteria for assessing garden biodiversity and its relation to green infrastructure on neighbourhood level, city level, and regional level.

\section{The indicator set}

The indicator set (see Table 2) is a more technical representation of the conceptual BIMBY framework as presented above. It shows more precisely how the yard features described above can be measured and how they can be treated in an analysis. Simple values have been attributed to the variables. They ask, e.g. for approximations of yard size, counting of species, indicating categories of soil cover or the presence of specific cultural factors like irrigation, bird-houses, and design style. The variables can be used in statistical programs. The results can be discussed in the contextual situation of the urban area and compared to local and regional datasets: what design and maintenance principles are popular and what roles do they play in the urban green infrastructure? Do the yards contribute or dis-contribute to local and regional biodiversity?
The final section on ecosystem services and disservices has to be further co-developed with stakeholders in the follow-up project: the experience of services and disservices is highly dependent on cultural values and preferences of residents (Kumar and Kumar 2008).

The visual conceptual framework can provide a basis for developing an understandable tool for citizens to explore their yards, gather data, discuss and compare the outcomes with other participants and become inspired to transform their gardens into biodiversity hotspots. The indicator set is intended for researchers who are able to analyse and evaluate the data in their contexts and potentially link them to other qualitative or qualitative datasets.

\section{Discussion}

The BIMBY framework we presented in this paper differs from other indicators for assessing biodiversity in domestic gardens in the way that it explicitly combines ecological factors, cultural elements and citizen preferences. Much information about ecological and cultural qualities can be derived by researchers on the basis of visual information that yards provide. However, the subjective elements (values, preferences, uses, conflicts, and beliefs about the role domestic gardens can play for the larger green infrastructure and biodiversity conservation) can only be communicated by the garden owners.

The BIMBY framework intends to transcend traditional indicator sets by functioning as an integrative and accessible tool for increasing societal dialogue about biodiversity, ecosystem services and sustainable living environments. Additional steps are to be taken where citizens will be involved as users and co-developers of the framework as an attractive tool (e.g. an interactive app, game or online platform) for exploring and learning about biodiversity, ecosystem services and sustainability in and beyond urban ecosystems. Ideally, the BIMBY tool will be able to fulfil transformative needs in society on multiple levels: (1) it transforms citizen science (Silvertown 2009) into a trans-disciplinary process of the co-production of "actionable knowledge" (Pohl et al. 2010; Lang et al. 2012; Wiek et al. 2012, p. 22; Lachmund 2013); (2) it transforms society towards higher levels of eco-literacy (Mitchell and Mueller 2009; Beatley 2011); (3) it helps transform cultural landscapes into biodiversity hotspots and better connected habitats (Rudd et al. 2002; Cameron et al. 2012; Mitchell et al. 2013). Integration of the data gathered by citizens with other datasets (e.g. spatial, demographic, climatological, biophysical, cultural, and psychological) can enrich the insights in emerging patterns, functional relationships and complex dynamics in socio-ecological systems. 
The presented BIMBY framework is not a fixed framework. It should be open and adaptive to specific environmental and cultural contexts in order to create a meaningful dialogue about biodiversity, sustainability and ecosystem services in society. Green gardens in Phoenix with lawns, colourful annuals and lush trees, for example, may increase the biodiversity of the city and the region and also provide short-term beneficial ecosystem services to residents, like cooling through evaporation and shade. However, such gardens consume more water resources than can be considered sustainable for an arid region. Municipal projects are now starting to promote xeric gardens that better fit the desert environment. For such reasons we consider it important that results that can be gained through the BIMBY indicator framework are always evaluated in the light of the specific socio-environmental context and of larger sustainability questions like: how do we find a healthy and sustainable balance in the way we protect biodiversity and work towards living together with it on our urbanising planet? How can we benefit most the services provided for free by nature and how can we become more serviceable towards non-human life in and beyond urban environments (Costanza et al. 1997; Lyytimäki et al. 2008; TEEB 2009 2011; Costanza et al. 2014)? Finally, how can we create new sustainable 'designparadigms' (Felson and Pickett 2005) where aesthetic pleasure and practical functionality of home gardens can become combined with ecological integrity and awareness of ecosystem processes and relations?

\section{Conclusions}

Can we find a healthy and sustainable balance in the way we protect biodiversity and work towards living together with it (Rosenzweig 2003) on our urbanising planet? This is a relevant and highly normative question and its discussion in society has to be fuelled by engaging citizens in exploring the biodiversity and ecosystem services in their gardens. By doing so, citizens can help deliver sound data that are sensitive to interpretation in local socio-cultural contexts and to regional climates and ecosystems. Citizens can also start thinking constructively about how they can transform their gardens to functional ecological nodes in the larger green infrastructure. We aim to contribute to this potentially transformative discussion by developing a framework that accounts for both ecological as well as cultural features, and for the more subjective values and life-style preferences represented in domestic gardens. Gardens are small parts of the urban ecosystem that are closest to residents and have a great potential for contributing to larger green infrastructure and (urban) ecosystem services. BIMBY is meant to become a flexible and adaptive tool that intends to contribute to the field of transdisciplinary and transformative knowledge production (Lang et al. 2012; Wiek et al. 2012) in order to advance sustainability in and beyond our direct living environments.

Acknowledgments We would like to thank our ICIS colleagues for their valuable reflections and suggestions. Special thanks also to Elizabeth Cook, Mathieu Bruls, Jeroen Verbeek, Floortje Mennen and her father, Elke Havenstein, Pierre Buijs, Luc Habets, Tim van Wanroij, Hilde Gorissen en Torben Mulder for your pointed questions and valuable comments.

\section{References}

Appleton AF (2002) How New York City used an ecosystem services strategy carried out through an urban-rural partnership to preserve the pristine quality of its drinking water and save billions of dollars and what lessons it teaches about using ecosystem services. Conference paper at the Katoomba Conference, Tokyo, November 2002

Baker PJ, Harris S (2007) Urban mammals: what does the future hold? An analysis of the factors affecting patterns of use in residential gardens in Great Britain. Mamm Rev 37:297-315

Beatley T (2011) Biophilic cities. Integrating nature into urban design. Island Press, Washington, D.C.

Beumer C, Martens P (2014) BIMBY's first steps: a pilot case study on biodiversity and ecosystem services in domestic front-yards in Phoenix and Maastricht. Urban Ecosyst (in review)

Bolund P, Hunhammar S (1999) Ecosystem services in urban areas. Ecol Econ 29:293-301

Burghardt KT, Tallamy DW, Shriver G (2008) Impact of native plants on bird and butterfly biodiversity in suburban landscapes. Conserv Biol 23(1):219-224

Butler D, Spencer N (2010) The century of the city. Nature 467 (21 October)

Cameron RWF, Blanuša T, Taylor JE, Salisbury A, Halstead AJ, Henricot B, Thompson K (2012) The domestic garden-its contribution to urban green infrastructure. Urban For Urban Green 11(2):129-137

Caro T (2010) Conservation by proxy. Indicator, umbrella, keystone, flagship, and other surrogate species. Island Press, London

Casey ES (2011) The edge(s) of landscape: a study in limnology. In: Malpas J (ed) The place of landscape: concepts, context, studies. MIT Press, Massachusetts

CBD (2007) Cities and biodiversity. Paper presented at the conference of the parties 9, 2007, Curitiba

CBD (2011) Strategic plan for biodiversity 2011-2020 and the Aichi targets: living in harmony with nature. UN-CBD-UNEP, Montreal

Chowdhury RR, Larson K, Grove M, Polsky C, Cook E (2011) A multi-scalar approach to theorizing socio-ecological dynamics of urban residential landscapes. Cities Environ 4(1):1-19

Cilliers S (2010) Social aspects of urban biodiversity-an overview. In: Müller N, Werner P, Kelcey JG (eds) Urban biodiversity and design. Wiley-Blackwell, London

Cook EM, Hall SJ, Larson KL (2012) Residential landscapes as social-ecological systems: a synthesis of multi-scalar interactions between people and their home environment. Urban Ecosyst 15:19-52

Cornelis J, Hermy M (2004) Biodiversity relationships in urban and suburban parks in Flanders. Landsc Urban Plan 69:385-401

Costanza R, D'Arge R, De Groot R (1997) The value of the world's ecosystem services and natural capital. Nature 387:253-260 
Costanza R, De Groot R, Sutton P, Van der Ploeg S, Andersond SJ, Kubiszewski I, Farber S, Turner RK (2014) Changes in the global value of ecosystem services. Glob Environ Change 26:152-158

Davies CE, Moss D, Hill MO (2004). EUNIS habitat classification revised: report to the European Environment Agency and the European Topic Centre on Nature Protection and Biodiversity

Davis JG, Whiting D (2013) Choosing a soil amendment. Retrieved 3 June 2013, from http://www.ext.colostate.edu/pubs/garden/ 07235.html

DBG (2013) Desert botanical garden. Retrieved 9 August 2013, from http://www.dbg.org/

Dearborn DC, Kark S (2009) Motivations for conserving urban biodiversity. Conserv Biol 24(2):432-440

Dewaelheyns V, Elsen A, Vandendriessche H, Gulinck H (2013) Garden management and soil fertility in Flemish domestic gardens. Landsc Urban Plan 116:25-35

Diamond J (1975) The island dilemma: lessons of modern biogeographic studies for the design of natural reserves. Biol Conserv 7:129-146

Dunn RR, Gavin MC, Sanchez MC, Solomon JN (2006) The pigeon paradox: dependence of global conservation on urban nature. Conserv Biol 20(6):1814-1816

Farinha-Marques P, Lameiras JM, Fernandes C, Silva S, Guilherme F (2011) Urban biodiversity: a review of current concepts and contributions to multidisciplinary approaches. Innovation Eur J Soc Sci Res 24(3):247-271

Felson A, Pickett STA (2005) Designed experiments: new approaches to studying urban ecosystems. Front Ecol Environ 3(10):549-556

Francis RA, Lorimer J (2011) Urban reconciliation ecology: the potential of living roofs and walls. J Environ Manag 92:1429-1437

Galluzzi G, Eyzaguirre P, Negri V (2010) Home gardens: neglected hotspots of agro-biodiversity and cultural diversity. Biodiversit Conservation 19:3635-3654

Gandy M (2004) Rethinking urban metabolism: water, space and the modern city. City 8(3):363-379

Gaston KJ, Smith RM, Thompson K, Warren PH (2005a) Urban domestic gardens (II): experimental tests of methods for increasing biodiversity. Biodivers Conserv 14(2):395-413

Gaston KJ, Warren PH, Thompson K, Smith RM (2005b) Urban domestic gardens (IV): the extent of the resource and its associated features. Biodivers Conserv 14:3327-3349

Goddard MA, Dougill AJ, Benton TG (2010) Scaling up from gardens: biodiversity conservation in urban environments. Trends Ecol Evol 25(2):90-99

Grimm NB, Grove JM, Picket STA, Redman CL (2000) Integrated approaches to long-term studies of urban ecological systems. In: Marzluf JM, Schulenberger E, Endlicher W, Alberti M, Bradley G, Ryan C, Simon U, ZumBrunnen C (eds) Urban ecology: an international perspective on the interaction between humans and nature. Springer, New York

Groot RSD, Wilson MA, Boumans RMJ (2002a) A typology for the classification, description and valuation of ecosystem function, goods and services. Ecol Econ 41(3):393-408

Groot RSD, Wilson MA, Boumans RMJ (2002b) A typology for the classification, description and valuation of ecosystem function, goods and services. Ecol Econ 41(3):393-408

Hancock J (2010) The case for an ecosystem service approach to decision-making: an overview. Biosci Horiz 3(2):188-196

Hart JL (2007) Biodiversity and edge effects: an activity in landscape ecology. J Nat Resour Life Sci Educn 36:103106

Hermy M, Cornelis J (2000) Towards a monitoring method and a number of multifaceted and hierarchical biodiversity indicators for urban and suburban parks. Landsc Urban Plan 49(3-4): $149-162$

Hope D, Gries C, Casagrande D, Redman CL, Grimm N, Martin C (2006) Drivers of spatial variation in plant diversity across the Central Arizona-Phoenix ecosystem. Soc Nat Resour 19:101-116

IVN (2013) Tuinreservaten. Retrieved 6 August 2013, from http:// www.ivn.nl/projecten/tuinreservaten-0

Jim CY (2013) Sustainable urban greening strategies for compact cities in developing and developed countries. Urban Ecosyst 16:741-761

Jorgensen A, Keenan R (2012) Urban wildscapes. Routledge, New York

Kendal D, Williams NSG, Williams KJH (2012) A cultivated environment: exploring the global distribution of plants in gardens, parks and streetscapes. Urban Ecosyst 15:637-652

Keylock CJ (2005) Simpson diversity and the Shannon/Wiener index as special cases of a generalized entropy. Oikos 109(1):203-207

Kumar M, Kumar P (2008) Valuation of the ecosystem services: a psycho-cultural perspective. Ecol Econ 64:808-819

Kurz T, Baudains C (2012) Biodiversity in the front yard: an investigation of landscape preference in a domestic urban context. Environ Behav 44(166):166-196

Lachmund J (2013) Greening Berlin. The co-production of science, politics and urban nature. The MIT Press, London

Lang DJ, Wiek A, Bergmann M, Stauffacher M, Martens P, Moll P, Swilling M, Thomas CJ (2012) Transdisciplinary research in sustainability science: practice, principles, and challenges. Sustain Sci 7(Suppl 1):25-43

Larsen L, Harlan SL (2006) Desert dreamscapes: residential landscape preference and behavior. Landsc Urban Plan 78:85-100

Larsen L, Swanbrow L (2006) Postcards of Phoenix: images of desert ambivalence and homogeneity. Landsc J 25(2-6):205-217

Larson KL, Casagrande D, Harlan S, Yabiku ST (2009) Residents' yard choices and rationales in a desert city: social priorities, ecological impacts, and decision tradeoffs. Environ Manag 44:921-937

Larson KL, Cook E, Strawhacker C, Hall SJ (2010) The influence of diverse values, ecological structure, and geographic context on residents' multifaceted landscaping decisions. Hum Ecol 38:747-761

Loram A, Warren PH, Gaston KJ (2008) Urban domestic gardens (XIV): the characteristics of gardens in five cities. Environ Manag 42:361-376

Lyytimäki J, Petersen LK, Normander B, Bézak P (2008) Nature as nuisance? Ecosystem services and disservices to urban lifestyle. Environ Sci 5(3):161-172

Martin CA (2008) Landscape sustainability in a Sonoran desert city. Cities Environ 1(2):1-16

Mathieu R, Freeman C, Aryal J (2007) Mapping private gardens in urban areas using object-oriented techniques and very highresolution satellite imagery. Landsc Urban Plan 81:179-192

Matteson KC, Ascher JS, Langellotto GA (2008) Bee richness and abundance in New York city urban gardens. Ann Entomol Soc Am 101(1):140-150

McKinney ML (2002) Urbanization, biodiversity, and conservation. BioScience 52(10):883-890

McNeely JA, Faith DP, Albers HJ, Dulloo E, Goldstein W, Groombridge B (2005) Biodiversity. In: Chopra K, Leemans R, Kumar P, Simons H (eds) Ecosystems and human well-being: policy responses, Chap 5, vol 3, pp 119-173

MEA (2005) Ecosystems and human well-being. Biodiversity synthesis. World Resources Institute, Washington, DC

Mee WR (1990) Highlights of the city of Phoenix water conservation program. J Contemp Water Res Educ 83:25-30 
Millard A (2010) Cultural Aspects of Urban Biodiversity. In: Müller N, Werner P, Kelcey JG (eds) Urban biodiversity and design. Wiley-Blackwell, London

Miller JR, Hobbs RJ (2002) Conservation where people live. Conserv Biol 16(2):330-337

Mitchell DB, Mueller MP (2009) A philosophical analysis of David Orr's theory of ecological literacy: biophilia, ecojustice and moral education in school learning communities. Cult Sci Educ 6:193-221

Mitchell MGE, Bennett EM, Gonzalez A (2013) Linking landscape connectivity and ecosystem service provision: current knowledge and research gaps. Ecosystems 16(5):894-908

Müller N, Kamada M (2011) URBIO: an introduction to the International Network in Urban Biodiversity and Design. Landsc Ecol Engl 7(1):1-8

Müller N, Werner P, Kelcey JG (eds) (2010) Urban biodiversity and design, vol vol 7. Wiley-Blackwell, Oxford

Nagendra H (2002) Opposite trends in response for the Shannon and Simpson indices of landscape diversity. Appl Geogr 22(2): 175-186

Nassauer JI (1995) Messy ecosystems. Orderly frames. Landsc J 14(2):161-170

Norton BG, Noonan D (2007) Ecology and valuation: big changes needed. Ecol Econ 63:664-675

Noss RF (1990) Indicators for monitoring biodiversity: a hierarchical approach. Conserv Biol 4(4):355-364

Nunes P, van den Bergh J (2001) Economic valuation of biodiversity: sense or nonsense? Ecol Econ 39:203-222

NWF (2013) Garden for wildlife. Make habitat at home. Retrieved 30 July 2013, from http://www.nwf.org/How-to-Help/Gardenfor-Wildlife.aspx?campaignid=WH10DGWP\&s_src=CWH_Wild life_Navigation

Opschoor JB (1998) The value of ecosystem services: whose values? Ecol Econ 25:41-43

Palmer MA, Menninger HL, Bernhardt E (2010) River restoration, habitat heterogeneity and biodiversity: a failure of theory or practice? Freshw Biol 55(Suppl 1):205-222

Pohl C, Rist S, Zimmermann A, Fry P, Gurung GS, Schneider F, Speranza CI, Kiteme B, Boillat S, Serrano E, Hirsch Hadorn G, Wiesmann U (2010) Researchers' roles in knowledge coproduction: experience from sustainability research in Kenya, Switzerland, Bolivia and Nepal. Sci Public Policy 37(4):267-281

Puppin de Oliveira JA, Balaban O, Doll CNH, Moreno-Peñaranda R, Gasparatos A (2011) Cities and biodiversity: perspectives and governance challenges for implementing the convention on biological diversity (CBD) at the city level. Biol Conserv 144(5):1302-1313

Qviström M (2013) Searching for an open future: planning history as a means of peri-urban landscape analysis. J Environ Plan Manag 56(10):1549-1569

Rosenzweig ML (2003) Reconciliation ecology and the future of species diversity. Oryx 37(2):194-205

Rudd H, Vala J, Schaefer V (2002) Importance of backyard habitat in a comprehensive biodiversity conservation strategy: a connectivity analysis of urban green spaces. Restor Ecol 10(2):368-375
Samnegård U, Persson AS, Smith HG (2011) Gardens benefit bees and enhance pollination in intensively managed farmland. Biol Conserv 144(11):2602-2606

Savard JPL (2000) Biodiversity concepts and urban ecosystems. Landsc Urban Plan 48(3-4):131-142

Shin HB (2012) Looking back and ahead: lessons from the 2008 Beijing Olympic Games. http://eprints.1se.ac.uk/46544/1/blogs. 1se.ac.uk-Looking_back_and_ahead_Lessons_from_the_2008_ Beijing_Olympic_Games.pdf

Silvertown J (2009) A new dawn for citizen science. Trends Ecol Evol 24(9):467-471

Smith RM, Thompson K, Hodgson JG, Warren PH, Gaston KJ (2006) Urban domestic gardens (IX): composition and richness of the vascular plant flora, and implications for native biodiversity. Biol Conserv 129(3):312-322

Spellerberg IF, Ferdor PJ (2003) A tribute to Claude Shannon (1916-2001) and a plea for more rigorous use of species richness, species diversity and the 'Shannon-Wiener' index. Glob Ecol Biogeogr 12:177-179

St.Hilaire R, VanLeeuwen DM, Torres P (2010) Landscape preferences and water conservation choices of residents in a high desert environment. HortTechnology 20(2):308-314

Sukopp H (2008) On the early history of urban ecology in Europe. In: Marzluf JM, Bradley G, Shulenberger E, Endlicher W, Alberti M, Ryan C, Simon U, ZumBrunnen C (eds) Urban ecology. Springer, New York, pp 79-97

TEEB (2009) The economics of ecosystems and biodiversity for national and international policy makers: summary: responding to the value of nature. UNEP, Bonn

TEEB (2011) TEEB manual for cities: ecosystem services in urban management. TEEB

Tzoulas K, James P (2010) Making biodiversity measures accessible to non-specialists: an innovative method for rapid assessment of urban biodiversity. Urban Ecosyst 13:113-127

Tzoulas K, Korpela K, Venn S, Yli-Pelkonen V, Kaźmierczak A, Niemela J, James P (2007) Promoting ecosystem and human health in urban areas using Green Infrastructure: a literature review. Landsc Urban Plan 81(3):167-178

Van Heezik Y, Dickinnson KJM, Freeman C (2012) Closing the gap: communicating to change gardening practices in support of native biodiversity in urban private gardens. Ecol Soc 17(1):34

Vrščaja B, Poggioa L, Marsana FA (2008) A method for soil environmental quality evaluation for management and planning in urban areas. Landsc Urban Plan 2(4):81-94

Wiek A, Ness B, Schweizer-Ries P, Brand FS, Farioli F (2012) From complex systems analysis to transformational change: a comparative appraisal of sustainability science projects. Sustain Sci 7(Suppl 1):5-24

Zerbe S, Maurer U, Schmitz S, Sukopp H (2003) Biodiversity in Berlin and its potential for nature conservation. Landsc Urban Plan 62:139-148

Zheng B, Zhang Y, Chen J (2011) Preference to home landscape: wildness or neatness? Landsc Urban Plan 99:1-8

Zube EH, Simcox DE, Law CS (1986) The oasis image of two desert cities. Landsc Res 11(3):7-11 